DOI: http://dx.doi.org/10.24093/awejtls/vol1no1.11

\title{
The Monster Unleashed: Iraq's Horrors of Everyday Life in Frankenstein in Baghdad
}

\author{
Hani Elayyan \\ Liberal Arts Department \\ American University of the Middle East \\ Egaila, Kuwait
}

\begin{abstract}
This paper analyzes Frankenstein in Baghdad, the winner of the 2014 International Arabic Fiction Prize by Iraqi novelist Ahmed Saadawi. I argue that by borrowing the story of Mary Shelley's monster in Frankenstein, Saadawi manages to pinpoint the roots of the terrorism that has plagued Iraq since the American occupation. Terrorism emanates from fear. Fear is the monster that has been unleashed by the collapse of central authority which resulted in what Judith Butler has called 'a precarious life' in which sudden and violent death is always looming. In addition, the struggle for power among the new players in the Iraqi scene leads to selfishness, demagogy, and exploitation. The novel stresses the need to acknowledge that no one is free of blame. By acknowledging that that nobody is purely a victim or a victimizer, and by taking responsibility for one's deed, there might be hope for a way out of the horrors of the civil strife and carnage.
\end{abstract}

Key Words: Arabic fiction, Frankenstein in Baghdad, Saadawi, Terrorism in Iraq

Cite as: Elayyan, H. (2017). The Monster Unleashed: Iraq's Horrors of Everyday Life in Frankenstein in Baghdad. Arab World English Journal for Translation \& Literary Studies, 1(1). DOI: http://dx.doi.org/10.24093/awejtls/vol1no1.11 


\section{The Monster Unleashed: Iraq's Horrors of Everyday Life in Frankenstein in Baghdad}

In Frankenstein in Baghdad, the winner of the 2014 International Arabic Fiction Prize, Iraqi novelist Ahmed Saadawi borrows the story of Mary Shelley's monster in Frankenstein to depict the horrors of life in Baghdad in the wake of the American occupation in 2003. Saadawi manages to pinpoint the roots of the terrorism that has plagued Iraq since then, which emanates from the Frankenstein in every one of us that is unleashed by the fear of what Butler(2004) has called "a precarious life"(p. XVIII) in which sudden and violent death always looms large and depends completely on the acts of people who we do not know and whose motivations we cannot fathom.

Fear has been ingrained in the lives of Iraqis since the days of the Baath Party rule, when violence was the main tool in the state's toolbox of strategies to subjugate the people and guarantee acquiescence to the one- party rule. The state spread fear among citizens through harsh punishments for all acts of disobedience, and through a network of spies and informants who made the average Iraqi fear to express political opinions even to very close friends and family. Unfortunately, the state of fear did not end with the collapse of the former regime, as the occupation of Iraq and the failed policies of the Coalition Provisional Authority led to more violence and sectarian war. This novel tells the story of the violence that erupted after the occupation and seeks to investigate the reason for the increase in violence and terrorism in the years that followed the occupation.

The novel tells the story of Hadī al - Attāk, a scrawny, alcoholic bric-a-brac merchant who decides to collect the body parts of people who have been killed in terrorist attacks and stitches them together as a corpse. When a lost soul of a terrorist bombing attack's victim enters the corpse, the creature comes to life and launches a revenge campaign to destroy the murderers who have killed the people who gave him each part of his body, and in the meantime commanding a following of dedicated disciples. The monster terrorizes Baghdad, a city where sometimes arriving a few minutes early or late to a place could mean the difference between, say, dying in a car bombing, or narrowly escaping death but witnessing the horrific scene of maimed bodies and destruction. Although hundreds of thousands of Iraqis have died since the occupation, That violent death carries no promise of regeneration or "sublimity" but serves as a sign and precipitator of total degeneration and waste'(Cole, 2009, p.1632).

The creature commands a following of dedicated disciples who gather around him and hope he would lead them out of the chaos to safety. As a result of his acts, he becomes the target of state security apparatus and journalists who take a great interest in him. We get to know the story of one journalist who writes about him and popularizes his story and the Brigadier-General who is seeking to arrest him, as well as the stories of some of the inhabitants of the Batawyin neighborhood in which the creature was "born."

Batawyīn neighborhood, a center of a Christian minority in Rusafa District in Baghdad, is almost a character in the novel. It boasts complex layers of history from Jewish, to Christian, to Muslim, that have contributed to the make-up of the Iraqi national identity. Khoury (2016) argues that "to write the history of cities at war is to move from national narrative to one focused on urban communities." This is especially true in the case of Baghdad where each neighborhood experiences war in a totally different manner, depending on the ethnic and religious make-up of 
its inhabitants. The author chooses Batawyīn because it is very diverse in its inhabitants and history. Thus it may serves as a study of Baghdad writ small, as well as a study of fear, violence, justice, revenge, and human agency. The novel evokes issues of mourning and melancholy, and explores the legacy of the totalitarian regime that continues to hamper Iraq's dream of national reconciliation.

\section{The Birth of the Monster: The Father}

The author chose for the creature a plebian father in order to highlight the plight of the common man. Unlike the ambitious Victor Frankenstein, Hadī al - Attāq has a lowly job: To scavenge through people's junk for housewares and sell them to poor people who cannot afford new ones. He is an outsider, a dirty old man who lives on the margin of society. So what sent this man on his godlike mission of creation?

Hadī al - Attāq has a partner by the name of Nahim 'Arankī. His partner has a horsedrawn carriage that he uses to collect junk to sift through later on. Before getting married and moving to a separate house, he used to share the old house, known as the Jewish Ruins, with Hadī. Much younger and more conservative, he was like a son to Hadī. One day, however, a bomb explodes in the street, killing him together with his horse. The mixing of Nahim 'Arankī flesh with his horse's meat symbolizes the loss of his humanity.

When Hadī goes to collect the body of his partner from the morgue, the attendant tells him to put together a hand from here and a head from there to make up a body. Hadi gets depressed for some time, but later he gets down to business and decides tocollect the body parts that were left behind after every clean-up process following a bombing, and stitch them together into a human being. He does not have a name for this creature, and so calls him Shesma(what'sits- name).Hadī is hoping for some dignity for those body parts to extract them from the garbage and put them in one body. All he wants is for that one corpse to be given a proper burial. The last piece is a nose that completes the body. He later on thinks of dismembering the body again, but before he does that, the stray soul of the hotel guard takes refuge in the body and Frankenstein comes to life.

Hadi's act of creation explains why he is the protagonist, an initiator of action in the sense Hannah Arendt distinguished between action, labor, and work. Collecting junk is part of the daily labor that helps Hadi exist as a biological entity, but the act of creation moves him to a different level for "action has the closest connection with the human condition of natality; the new beginning inherent in birth can make itself felt in the world only because the newcomer possesses the capacity of beginning something anew, that is, of acting" (Arendt, 1998, p.7). His decision to act sets him above all the other characters in the story who simply react to his action. He wants to create a grievable life out of the ungrievable beings who were killed and forgotten, a commendable deed by any measure. Hadī's act of creation is his ultimate defense of human dignity, not only for those who died, but also for those who were alive but were, as Simone Weil argues, "an alternative human species, a hybrid of man and corpse"(as cited in Balibar, 2015, Afterward). These people, like his friend Nahim 'Arankī, "have become things for life. In their days there is no play, no space, no opening for anything that comes from within"(as cited in Balibar, 2015, Introduction). 
In addition to creating the Shesma, Hadi is a creator in an artistic sense. He is a skilled weaver of tales, a scavenger who is trying to create an object of beauty out of the shreds of humanity he encounters. He tells the story of the monster to the customers at 'Aziz al-Masri Café. For a free meal or the price of a bottle of alcohol, he would go into the details of how he made the Shesma and how he disappeared into the night. His story attracts many people among whom is the journalist, Mahmūd al- Sawadī, who covers the story in the magazine he works for and brings the Shesma to national attention.

Hadi is not without mistakes. He is trying to push old Elishua, the Chaldean lady who lived next door, to sell him the figurines in her house. However, unlike Faraj the realtor, he is not driven by greed and the wish to take over other people's properties. Rather, he has no ambitions beyond survival. His ability to act, and not simply to work, sets him apart from others and saves him as a character. He also has some qualms about the creature, and feels a little responsible for his deeds. The Shesma does not take him seriously as a father though, neither do other characters on the story who see him as a source of comic relief. However, later the story takes a more poignant direction when the Brigadier General's men raid Hadi's house, beat him up almost to death and rob him of the little money he has. At the end of the novel when he is injured in the final bombing and his face is disfigured, the police arrests him and announces he is Frankenstein.

The Shesma has taken from his father the ability to captivate people with his stories. And like him, he is a marginal character who is concerned with people who have been rejected and victimized. Frankenstein lets Hadi be arrested and scapegoated at the end, thus repeating the same story of hundreds of thousands of common people who are sacrificed in order for the leader to survive and thrive.

\section{The Birth of the Monster: The Mother}

Unlike Frankenstein's monster, the Baghdadi monster has a mother. The new creature comes to life when the lost soul of the security guard from the hotel finds that body as a new home after its original body was lost. Naked and disoriented, he leaves Hadī's shed and climbs up to the house next door where old Elishua lives.

A Chaldean, The old woman Elishua is the only stable character in the volatile world of the novel. After her son Daniel was enlisted to fight during the Iraqi- Iranian War twenty years ago and never came back, she insisted on waiting for him and refused to leave her house even after her husband died and her two daughters immigrated to Australia. Her faith in her son's return gives her life power, and she continues to reject her daughters' offer to move with them to Australia, as well as the pressure from Faraj the realtor to buy her house. She has complete faith in her patron saint, Saint George, that he will grant her wish and bring her son back.

Ladies in the neighborhood, whether Christian or Muslim, have mixed feelings about her. They think she is crazy to live alone in her 7-bedroom house, but some believe that she is a blessed woman and that her presence in the neighborhood protects them from terrorism. Elishua is surrounded by many people who want to see her gone. Lonely and without anyone to support her, the old lady has to be very strong to put out a fight against all the enemies. In many ways, she represents the ancient history of the country that has almost been stamped out by newer layers of history. She is becoming more of an anomaly in an age of Islamic sectarian struggle. 
Her house was next to the Jewish Ruins, yet another testimony to the complexity of the country and its history.

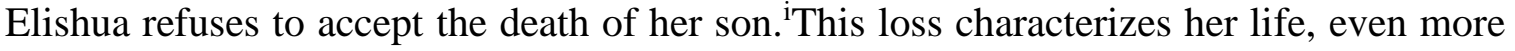
than the loss of her husband and the emigration of the two daughters. Her neighbors did not care about the death of one young man when thousands more were dying. She however has been grieving him for 20 years. She trusts that her patron saint will bring him back to her. So when Frankenstein climbs to her house from Hadī's shed, she immediately accepts him as her son, gives him her son's clothes and tends to his wounds. The following day she ends her mourning by buying meat, wearing a red bandanna, and telling her neighbors that her son is back. Twenty years of melancholic waiting for her son ends when she accepts Shesma as her son. But does she really believe that it is Daniel? And what are we to make of her accepting two substitutes for her Daniel: Shesma and, later on in the novel, her grandson, also called Daniel, who comes back from Australia and manages to convince her to join him and his mother?

In light of early Freudian examination of mourning and melancholia, Elishua's acceptance of the substitutes for her son can be seen as an act of severing the emotional connection to the lost object and being available for a new investment in a different object, or a different son who is even younger and reminds her of a time when she was a young mother (Lerner, 2007, p.46). However, the act can be seen differently, according to Judith Butler, as part of her attempt to "preserve the object as part of the ego"(Lerner, 2007, p.47). Slavoj Žižek(2002), in "Melancholy and the Act," deconstructs the relationship between melancholy and mourning, and opposes the view that mourning is an act of betrayal whereas melancholy is an act of faithfulness (p.658). Thus ending her mourning is not a process of betrayal of her roots in Iraq. The old woman decides to leave because maybe she wants to contribute to preserving the identity of her grandson who does not speak Arabic and is probably going to assimilate into the Australian society. Her departure is part of the experience of Iraqi Christians who, lacking the strong tribal or sectarian military support, are left with the only option of emigrating. She also wants to leave behind the horror of past and present wars, and live her final days in peace with her daughters and grandchildren. Thus, before leaving, she looks at the picture of her patron saint and ponders taking it with her. Finally, she brings a pair of scissors and cuts out the angelic face of the saint, almost like a halo around his head, and leaves behind the shield, the sword, and the dragon. Symbolically, she is leaving behind the memories of war and the binaries of good and evil, preferring rather to keep the peaceful memories of better times only.

Elishua represents memory in the time of national amnesia. Rejecting the official version of the Iraqi-Iranian War, her faith in her son's return is impressive. While her actions are not "Antigone-like disruptive claims of grief and grievance"(Mclvor, 2012, p.429), her refusal to accept Daniel's death would have been viewed uncomfortably by the Baathists who would prefer people to move on or partake in a nationally prescribed mourning that would celebrate the "martyrdom" of the young men in the service of their nation. Similarly, her refusal to forgive Abu Zaydūn, the barber who enlisted her son in the war, despite her Pastor's invocation of Christian values, shows that she resists any pacifist religious quelling of her anger. The common belief that the old woman is the protector of the neighborhood is confirmed at the end of the novel. Once she leaves with her grandson, terrorism manages to hit Batawyīn with a mega bombing that destroys her house, the hotel, and Um Salīm's house. Regardless of the real role 
the old woman played in protecting the neighborhood, she gave them some faith in a divine power that can help protect them from terror.

From his mother, Frankenstein learns perseverance and the unwavering faith in his goals. However, unlike her, he does not have a clear cause. His motivations are tainted. In the last scene in the novel, he is seen stroking Elishua's old cat, whom she left behind. He is the militaristic part of the picture of the angel that she discarded, and while he claims he is fighting the devil, he is not much better than the dragon in that painting.

\section{The Birth Place}

Batawyīn has multiple layers of history from Jewish, to Christian, to Muslim. Many inhabitants claim they were original citizens and others came from distant towns in Iraq, but, the narrator argues, nobody knows who is new or original because they have been there for a long time. They all seek to make sense of the new Iraq after the American occupation. Everyone is trying to take advantage of the shifting dynamic to make a living or accumulate a fortune. They go about their lives in an almost normal manner, because that would take their minds off the possibility of death lurking in every corner. Faraj the realtor, for example, is acquiring houses of people who have fled the country. For him, the chaos is a business opportunity to expand his little empire. When some young men from a non- governmental organization come to the neighborhood to take pictures of old houses and try to conserve the heritage of the place, he and his men beat them up and drive them out of the area. He is always on the alert watching out for anyone who tries to interfere in his plans to acquire new houses and to drive their residents out. While his motives are selfish, his acts show the effort involved in taking cities apart and redrawing communities (Stephens, 2007, p.162). The post- occupation weakening of central authority releases selfish desires in individuals to profiteer from the war.Many, like him, also found opportunity in the new Iraq. The clearest example is Al-Sa'̄idi who, as an owner of a magazine is also trying to buy a printing press in order to take advantage of the election year to print leaflets and other publications.

Total chaos is the name of the game in the new Iraq. No one knows whether he/she will be killed in a bombing attack, get shot by a sniper, or tortured to death. Batawyīn has become a hotbed of vice, crime, and corruption. Such a place calls for some drastic solutions and that is what Frankenstein decides to do.

\section{The Monster}

Like his namesake, Frankenstein shows characteristics of the gothic monster. As. Devetak(2005) points out, the gothic narratives revolve around "haunted houses, ghosts, monsters, and the undead"(p.622). While the gothic was originally a reaction to both the Enlightenment and the French Revolution, it has proved useful whenever old paradigms broke down, and periods of uncertainty and chaos ensued. Thus, Devetak (2005) rightly points out that George Bush invoked the gothic in his description of September 11, and the lead-up to the war in Afghanistan and Iraq when he spoke of "rouge and terrorist states who are equally dark, perverse, and indomitable forces"(p. 622).

But if the gothic connection was useful to the enemies of Iraq, how did the same genre serve the purposes of the Iraqi writer describing his country 12 years after Bush's remarks? Devetak (2005) adds that monsters were "metaphors for human anxieties" and that is clear in the 
case of Iraq after the monsters of sectarianism and terrors have been unleashed, partly as a result of the total collapse of the central government that had, for better or worse, held all the warring factions in check through its cruel state security apparatus (p. 624). After the state's monopoly on violence was lifted, all segments of society claimed their share of violence, and used the unlimited supply of weapons to terrorize everyone else who did not belong to their factions or tribes.

We can read Frankenstein as a reaction to, in Judith Butler's term, the "corporeal vulnerability" of all the victims of violence in Iraq (Butler, 2004, p.19). He represents all the humans who were relegated to an inferior, sub-human status. However, he, being a modest project of human dignity, has been transformed by the people into a dream of a political savior. He soon commands a following of people who are not given names but epithets such as the Lesser Madman, the Greater Madman, the Sophist, the Enemy, and the Wizard. All of these have a following of their own, and a cult of political change and revolution forms around them. Those leaders could represent the different new brands of politicians and political movements that have appeared on the Iraqi scene after the fall of the Baathist regime. For example, the story nearly predicts the emergence of ISIS, led by an ex-convict who has managed to galvanize criminals and malcontents in support of his so called Islamic State.

The creature, which is later called Frankenstein by the journalist, is, like all children, born pure because he was born out of the bodies of victims. Everybody sees in him hope for revenge, maybe even a new beginning for the country. For the Lesser Madman, Frankenstein is the quintessential Iraqi: He is made up of parts of people from every background. To the Great Madman, Frankenstein represents the tool of destruction that will pave the way for the appearance of the Savior, so he is helping him to make it possible for the Savior to come. As for the Greater Madman, Frankenstein is the Savior.

Frankenstein at the beginning sounds like a savior. He wants to exact revenge on murderers, criminals, and terrorists. However, ironically, his first victims are the three beggars who attack him and whom he makes to strangle one another. According to Brigadier Surūr, nobody would miss them except the traffic lights and the dark alley they lived in.

His next victim is Abu Zaydūn the barber, the man who, during the Iraqi-Iranian War with Iran, managed to send many young men to their death, including Daniel, the old woman's only son, and Salìm, the son of her neighbor. Whenever Frankenstein takes revenge for one of the people whom he borrowed body parts from, that body part would fall off. That means Frankenstein has to keep killing in order to make up the missing parts. He starts killing innocent people in order to survive, and he develops villainous inclinations.

Selfishness seems to be a salient feature in the majority of the characters in the novel. It is suggested that selfishness is a natural reaction to fear and insecurity. The novel explores the different reactions characters have to the "precarious" life they are leading, and the Hobbesian "war of all against all"(Balibar, 2005, Afterward). However, before discussing the fear of the new wave of terrorism, the novel refers to the state of fear that Iraqis lived in under the Baathist regime, for fear correlates with dictatorial, totalitarian regimes. 
The Baathist regime was very violent. During its 10-year war with neighboring Iran, hundreds of thousands of lives were lost. Young men were drafted and sent to the war front. Two of the victims we hear of in the novel are Daniel, son of Elishua, and Salim, son of Um Salim. The young men were pursued by Abu Zaydūn the barber, whose job was to keep track of the young men in the neighborhood and draft them. The historian Dina Rizk Khoury (2016) explains that the mapping of Iraqi cities by the Bath party started in 1979, when the government started assessing each individual's political leanings and conformity to party rules. In each neighborhood, a "headman" functioned as a record keeper and "the linchpin of this information system." Abu Zaydūn was one such headman, probably chosen for the access that his job gave him to all the men in the neighborhood. Thus, under the Baath party's rule, people always feared being reported to the authorities by the network of spies and party informants. It is true that the Iraqi society was less violent during the Baath party rule, but that was due to the fact that under the dictatorship of the Baathist regime, the state monopolized the use of violence and meted out harsh and violent punishment to anyone who challenged the rules. So far from being a peaceful society, violence was part of the way the country was run. When the central government disappeared, individuals took over the reins of power and used the same violent tactics to achieve their political goals.

In addition to violence, another cause of the pathology of the society is repression. Many forces in society colluded to suppress the citizens because a person who falls in line with government expectations, will also conform to the expectations of his family, tribe, or sect. When the state is all-powerful, smaller social groupings can invoke the state's power to control members of the group. As a result, suppression remains a powerful force, even after the toppling of that Baathist regime. In fact, the novel opens with an act of suppression in the form of inhibition of discourse. The investigative commission's report about Frankenstein forbids the author of the novel to write about the events of the emergence of Frankenstein and denies its existence. Just like in the days of the Baath regime, citizens are not allowed to know the facts and have to, instead, accept state propaganda as truth. However, the author challenges the state and writes the novel. The author, just like many other ambitious men, can get away with much more than before thanks to the weakening of central authority in the country, but not due to a real turnabout in policy.

The novel condemns the new breed of Iraqi leaders who, instead of transforming the country into a democracy, seek only to wield more power and take the place of the old elite. The new Iraq has its new class of powerful men, who are ambitious, rich, and charming but not less harmful than the politicians of the former regime. The exemplary new Iraqi politician is Bahir alSa'ìdi, the well-connected owner of the Truth Magazine who suggests the name 'Frankenstein' for the monster. He keeps company with politicians in the Green Zone; the American, and Brigadier-General Surūr, a former Baathist who, through the support of the Americans, was not purged and headed the Investigation and Tracking Department, which was on Frankenstein's trail. Bahir al-Sa'īdi turns Frankenstein into a popular sensation by assigning Mạmmūd alSawadī , his protégé, to the case and encouraging him to pursue the monster. Al-Sa'īdi understands and uses the emotions of fear to push his personal agenda. Although a minor character, al-Sa'idi is very important for the development of both the theme and the plot of the novel. 
Sa'̄idi’s relationship with Maḥmūd al- Sawadī is very significant as it demonstrates the predicament of young Iraqis who are committed to the betterment of their country but are misled and manipulated by the leadership. A young journalist from southern Iraq, he moved to Baghdad to escape a thug turned politician who sought revenge on him for writing an article about justice that led to the assassination of that thug's brother. In that article, Mạmūd al- Sawadī said that there were three types of justice: One imposed by the law, one imposed by heaven, and a vigilante justice enacted by concerned individuals. He added that any criminal should be brought to justice, any type of justice. After he published the article, that thug's brother was assassinated and the thug accused Maḥmūd al- Sawadī of instigating his brother's murder, so the latter fled his town for Baghdad. Ironically, he in the city he sees firsthand the dangers of vigilante justice as carried out by Frankenstein.

Internal displacement becomes very rampant in post-occupation Iraq, as many individuals are forced, because of fear and intimidation by sectarian militias, to leave their mixed neighborhood and move closer to their own people or to the capital where the central government still has more power. Mahmūd's story serves as a good example of this new reality of Iraq. He also escapes the south to Baghdad where the thug cannot reach him, but by the end of the novel he goes back because Baghdad is no longer safe. His story serves almost as a sub-plot to the story of Frankenstein. Just like the monster he is full of good intentions, but he veers off course as he starts pursuing his own selfish desires. Chance brings him to a small hotel in Batawyīn, the neighborhood where Frankenstein embarks on his campaign of terror. Mahmūd barely escapes the suicide attack that kills the hotel guard and is traumatized. The fear of terrorism is a transformative experience for him and the people of Baghdad. It transforms some of the usually benign objects into feared tools of destruction. One clear example is cars, which have become the preferred devices of destruction for suicide bombers. The trash truck that is used in the suicide attack at the hotel causes the death of the guard and others who are, symbolically and physically, treated as trash. Another source of fear is the big American cars with their tinted windows, carrying around people who work for the government or the security forces. Those cars notoriously carry people away to be questioned and often disappear for months or years even. Environed by the fear of terrorism and forced disappearance, Mahmūd attaches himself to the most powerful man he knows, Al-Sa'īdi. The natural instinct to seek protection, however, turns into an unhealthy dependence and willingness to idolize this man. Despots, it seems, catapulted to power by the common people who depend on them for protection. These new leaders have no principles, and are open to deals with anyone, as long as they can gain more power.

Despite the purge of the Baath, the novel reveals that some of the former Baathist leaders managed to hold on to power. Al-Sa'īdi takes Mạ̣mūd to visit his friend, Brigadier-General Surūr in his office in the Green Zone. According to Al-Sa'īdi, Surūr carries out assassinations, which is why Sa'îdi wanted to befriend him in order to avoid being targeted by him. After the visit, Al-Sa'īdi comments that Surūr's office smells of sweet apples because that was the favorite smell for Baathists, a reference to the chemical weapons the Baathist regime used to attack Halabja, a Kurdish village in Iraqi Kurdistan. The smell symbolizes the potential for tragedy to happen again because the leaders have not changed their colors and are willing to resort to the deadliest measures if they deem it necessary. The visit leaves Mạ̣mūd al- Sawadī with a sense of fear. 
In the face of the constant fear of death, individuals have to make major decisions: Do they leave the country, do they go into hiding, or do they forsake the pleasures of life and prepare for death. Mahmūd al- Sawadī, however, responds to the fear of everyday life with a hedonistic pursuit of pleasure and success. He seeks to emulate his boss, by dressing up, drinking expensive liquor, and living beyond his means to impress others. He also competes for the love of Nawāl, the movie director who is a friend, and possibly girlfriend, of Bahir al-Sa’’̄idi. By drinking alcohol, Maḥmūd seeks to drown his sorrows. Like old Elishua, Maḥmūd al- Sawadī is grieving. He grieves for his father who led a respectable life as a teacher and family man. When the father died, the family discovered his journal in which he talked about his repressed sexual desire for women, including some elderly neighbors. The brothers decide to burn the journal in order to protect their status in the community. However, Mahmūd resents that erasure of his father's real life and wants to tell the story. Thus when Hadi offers to tell him the story of Frankenstein in return for a secret, Mạ̣mūd al- Sawadī starts telling him about his family; that his family was originally Median but converted to Islam generations ago. He tells him about his father's journal and all the buried secrets. Like Hadi, Mahmūd al- Sawadī uses narrative as a means to resist loss, an act which coincides with Freud's theory of original act of violence against the father and the grieving that follows. Grief is part of the national and personal lives, and it is hard to decide where it originates. Are individuals injured and hurt to the degree that they are pushing the nation over the edge? Is the political system so corrupt that it is unhinging the balance of the individual? Regardless of the reason, individual pathologies stem from different familial, social, and political reasons. One cannot respond to external pressures wisely if nothing in the family, community, or society has prepared him or her to deal with ethical dilemmas.

At the familial level, Mahmūd struggles to build a connection to his father that is true to the father's life, not to the family's expectations and social stereotypes. After the father passes away, he seeks to build a similar relationship with Al-Sa'īdi. Maḥmūd 's relationship to AlSa'îdi could be read as an attempt to find a substitute for his father. This man represents the realization of the father's repressed desires. Al-Sa'īdi has no problem with sleeping with Nawāl and pursuing other women as well as political office. Maḥmūd al- Sawad̄̄ starts chasing Nawāl as a way of becoming Al-Sa'īdi. He emulates his ways by dressing up in suits and drinking expensive alcohol. Even when he sleeps with Zinah the prostitute, he insists on calling her Nawāl, not heeding her protests about the old-fashioned name. Like his father, he is pursuing an older woman and wants to achieve what his father enjoyed only in his private fantasies recorded in his journal. Thus, the fear of the authorities is not the only fear that people of Iraq had to deal with. Every individual had to be careful not to breach the community's expectation of proper behavior. The consequences of not abiding by social rules are dire, and could include ostracization.

In addition to pressure by one's compatriots to display normative behavior, an individual is also monitored by the government to guarantee one's adherence to social and political expectations. Although there emerged a wider margin for freedom of speech in post-occupation Iraq, that did not mean total freedom of speech. Journalists were encouraged to expose the crimes of the former regime, but not to criticize the current one. This is why Al-Sa'îdi is forced into hiding and the government takes over the newspaper and closes it down. Mahmoud is faced with an ethical dilemma: Should he play the victim since he, too, is left with no salary, or should 
he bear his responsibilities towards the worker since he was the manager? He sells his Rolex watch, his laptop, and other belongings to pay off the secretary's salary. Like Nick Caraway in The Great Gatsby, Mahmoud decides to go back home, carrying with him the memories of that encounter with Frankenstein that would color his future years and leave him a wiser person. He is wiser because he recognizes that a journalist should act upon his own beliefs; he should not write about justice without being just to others. He also understands the dangers of vigilantism.

Mahmoud's feeling of responsibility towards the workers in the newspaper shows a developing sense of community that is based not on sect or family, but rather a sense of individual responsibility. Rather than advocating for a revival of an older society, he advocates for a new sense of community that recreates itself on a democratic basis. The notion of a new community is especially useful one in the case of Iraq, since restoring the past would always sit uneasily with many Iraqis for whom the past meant exclusion and persecution. A new Iraq would not be built by any liberating forces, but by its own people who learn to accept and even embrace difference.

In addition to accepting diversity, the people have to resist finding any point of reference outside Iraq. No matter how hard the situation is, they should not seek help from the outside, even if they get the best promises. After Mahmoud goes back to the south. He receives an email from Al-Sa'îdi that disturbs him. In the email, he says that when he took him to see Surūr, the intention was for the Fortuneteller to read Mahmoud's future because Al-Sa'īdi knew that Mahmoud was in for a very bright future, that he was going to be the next prime minister of Iraq. Mahmoud thinks of replying to him with the f-word, but he decides not to reply at all. However, Al-Sa'īdi keeps his power of manipulation by planting the idea in Mahmoud's mind. We do not know if Mahmoud would pursue that future, but it is clear that Al-Sa'īdi has a way of manipulating other. He is the new politicians, charismatic and manipulative. He is gone now, but it is clear that he is intent on coming back. Such characters always find a way to come back with an invading force or through their relationship with people in power. Thus the reader gets a feeling that the cycle of manipulation and violence could continue as long as the elite are driven by their selfish desires and motives.

\section{The end, or, the beginning}

In a county ruled by haphazard, blind violence, the idea of planning a future sounds ridiculous. Even when the best schemers get their way, chance can turn the tables on them. After Elishua leaves Baghdad, both Faraj the realtor and Hadi get what they want. Hadi buys the souvenirs in her house, and Faraj gets the house, in addition to Al-Orouba Hotel whose owner also decides to go back to his town in the south. However, in an existential twist and soon after Elishua's departure, a car bombing hits the neighborhood, razing Elishua's old house to the ground and damaging parts of Al-Ouroba Hotel and Um Salim's house. Hadi is injured and his face is disfigured, thus making him look like Frankenstein. On 21 of February, 2006, the authorities arrested him and declared he was Frankenstein. People all across Iraq went out on the streets and celebrated the end of the reign of terror. However, one person was watching the scene from a room inside the deserted hotel. That person was Frankenstein. That day on which the authorities declared the end of terror ironically preceded the day of the bombing of the Golden Mosque in Samara, the event that allegedly unleashed the Iraqi Civil War. The novel implies that Frankenstein was behind that bombing. Whether it was a true civil war or an insurgency, and whether it was an indigenous civil war in the making or the work of foreign elements (Derian, 
2008, p. 933), the events of that day put Iraq in the grasp of a violent insurgency that still haunts the country. This indomitable monster would continue its reign of terror for many years to come.

\section{Conclusion:}

In view of that life of the war of all against all, the options people find are limited: to emigrate, to stay and try to take advantage of the changing political scene to gain power and partake in a hedonistic pursuit of pleasure, or to give up one's will to any charismatic monster for protection. All the options are bad for the country, and the latter probably explains the rise of ISIS. The situation in Iraq is complicated further by the fact that terror continues to happen every day. There is no respite from the horrors of the new Iraq and the "cultural trauma" of sectarian war. Trauma, as Redfield (2007) argues, "involves blockage: An inability to mourn, to move from repetition to working through"(p. 56). When the violence keeps repeating itself, the voice of logic and rationality would be silenced.

The novel does not give a recipe how to rid Iraq of violence. It rather depicts the complexity of the issue, and the complicity of all Iraqis in the dilemma of their country. The end of the dictatorial regime did not bring the peace and prosperity everybody hoped for, because of the selfishness of individuals who sought to advance their gains from the war, at the expense of the country.

However, the novel is clear about a few things. Revenge is not the answer, Resorting to the Fortune Tellers and astrology (any twisted religious or ideological solutions that are not based on empirical evidence) or to a heavy-handed state security apparatus will not guarantee the transformation all seek. Politicians who want more gains are playing with fire that will ultimately burn them. Only when all parties to the violence admit that they are guilty, that there is no pure victims or absolute victimizers, maybe then the work of national reconciliation can start.

\section{About the Author:}

Dr. Hani Elayyan is an associate professor of English at the American University of the Middle East in Kuwait. He holds a PhD. In English from Southern Illinois University. His research interests include Arab- American Literature, Modern Arabic Fiction, and American Studies.

\section{Notes}

${ }^{1}$ Raphaeli (2007) points out that following the occupation of Baghdad, there were many exhumations to prove to mothers that their children were dead, so Elishua is not unique in her refusal to believe that Daniel was dead.

\section{References}

Arendt, H.(1998). The Human Condition. $2^{\text {nd }}$ ed. Chicago: University of Chicago Press. Balibar, E.(2015).Violence and civility: On the limits of political philosophy. Trans. G.M. Goshgarian. [ Kindle DX version]. Retrieved from Amazon.com. Butler, J.(2004).Precarious life: The power of mourning and violence. London: Verso. Cole, S.(2009). Enchantment, disenchantment, war, literature. PMLA, 124, (5), 16321647. 
Devetak, R.(2005). "The Gothic scene of international relations: Ghosts, monsters, terror and the sublime after September 11. Review of International Studies, 31, (4), 621643.

Derian, J.(2008). The Desert of the real and the simulacrum of war. International Affairs (Royal Institute of International Affairs 1944-), 84,( 5), 931-948.

Khoury, D.(2016). Making and unmaking spaces of security: Basra as battlefront, Basra insurgent, 1980-1991. In N. Fuccaro (ed.), Violence and the City in the Modern Middle East, (Ch. 8),[Kindle DX version]. Retrieved from Amazon.com.

Lerner, L.(2007). Mourning and subjectivity: From Bersani to Proust, Klein, and Freud.' Diacritics, 37, (1), 40-53.

McIvor, D.(2012). Bringing ourselves to grief: Judith Butler and the politics of mourning.' Political Theory, 40, (4), 409-436.

Raphaeli, N.(2007). Culture in post-Sadam Iraq. Middle East Quarterly, 14,( 3), 33-42.

Redfield, M.(2007). Virtual Trauma: The Idiom of 9/11. Diacritics, 37, (1), 5480.Saadawi, A.(2013). Aرانكنشتاين في بغداد [Frankenstein in Baghdad]. Beirut: Al-Kamel

VerlagStephens, A.(2007). Seven million Londoners, one London: National and urban ideas of community in the aftermath of the 7 July 2005 bombings in London.'

Alternatives: Global, Local, Political, 32, (2), 155-176.

Žižek, S.(2002). Melancholy and the act.' Critical Inquiry, 26, (4), 657-681. 